Archives of Agriculture and Environmental Science

\title{
Determination of intra and inter row spacing on the yield of pearl millet (Pennisetum glaucum L.) in the dry land areas of Wag Himra, eastern Amhara, Ethiopia
}

\section{Alemu Lakew and Tafere Berhanu*}

Amhara Regional Agricultural Research Institute (ARARI), Sekota Dry land Agricultural Research Center, P.O. Box, 62, Sekota, ETHIOPIA

"Corresponding author's E-mail: tafereberhanu@gmail.com

\section{ARTICLE HISTORY}

Received: 12 December 2018

Revised received: 10 February 2019

Accepted: 19 February 2019

\section{Keywords}

Inter row spacing

Intra row spacing

Pearl millet

\begin{abstract}
Recently in Ethiopia pearl millet has drawn a lot of attention as a replacement for maize and sorghum in the dry land areas because of its ability to reliably produce grains on a wide range of soils and harsh production environment. A field experiment was conducted during the 2014 cropping season on the Research sites of Abergele and Aybra, at Sekota dryland agricultural research Centre, eastern Amhara, Ethiopia, with the objective of to increase the productivity of pearl millet in the study areas of Wag-Himra Zone through optimizing its intra and inter-row spacing. The treatments considered in the study were consisting of four intra row spacing's $(5,10,15$ and $20 \mathrm{~cm})$ and four inter-row spacing $(30,50,60$ and $75 \mathrm{~cm})$ and making a total of sixteen treatments. The Randomized Complete Block Design factorial arrangement with three replications a plot size of $5 \mathrm{~m} \times 3 \mathrm{~m}$ was used. Based on the Combined analysis main effects of inter and intra row spacing by location showed significance difference $(p<0.05)$ for the parameters of grain yield. The heights grain yield was recorded from $50 \mathrm{~cm}$ and $5 \mathrm{~cm}$ inter and intra row spacing respectively, whereas the lowest grain yield was recorded from $60 \mathrm{~cm}$ and $75 \mathrm{~cm}$ with $20 \mathrm{~cm}$ inter and intra row spacing respectively. It is possible to recommend that, sowing of pearl millet with inter row spacing of $50 \mathrm{~cm}$ and $5 \mathrm{~cm}$ intra row spacing is effective in attaining higher grain yield in the study area.
\end{abstract}

(C)2019 Agriculture and Environmental Science Academy

Citation of this article: Lakew, A. and Berhanu, T. (2019). Determination of intra and inter row spacing on the yield of pearl millet in the dry land areas of Wag Himra, eastern Amhara, Ethiopia. Archives of Agriculture and Environmental Science, 4(1): 45-49, https://dx.doi.org/10.26832/24566632.2019.040107

\section{INTRODUCTION}

Pearl millet (Pennisetum glaucum) is the most important crop in the drier parts of semi-arid tropics and accounts for almost half of the global production of the millet species from amongst different species of millets cultivated (Singh et al., 2017; Vinoth and Ravindhran, 2017). As general estimate, global millet production is broken down into pearl millet (50\%), finger millet (10\%) and other millets $40 \%$. Over thirty percent of the population (over 100 million people) of Eastern and Central Africa (ECA) live in these semi-arid areas and rely on agriculture and livestock as their main livelihood (Mortimore et al., 2009; Disasa et al., 2016).

The communities in these areas depend on millets and sorghum as the main staple crop-providing source of food, and source of income (Champion and Fuller, 2018). As the conditions become drier, pearl millet is the only crop that is grown where normal rainfall does not permit the reliable production of sorghum (Jukanti et al., 2016). Production exceeds that of sorghum due to its draught-tolerant character and the reverse is the case as rainfall increases (Negi et al., 2017; Chisi and Peterson, 2019). Being able to thrive where habitats are harsh, it is perhaps the best of all life-supporting grain (FAO, 2000).

With respect to its nutritional value, research was conducting by Kodkany et al. (2013) which showed that pearl millet bread to contain more iron can provide young children with their full daily iron needs. His report further pointed out that it yields reliably well in regions too hot and too dry to consistently 
support good yield of maize or sorghum (Ullah et al., 2017). Pearl millet is a hardy warm-season, dry land cereal grain crop. It is largely grown in the drought-prone regions of Africa and Asia where it performs better than other cereals (Chisi and Peterson, 2019). In Ethiopia, one improved variety is released for production in the dry land areas of the country. Though the crop is grown in some dry areas of the country, agronomic factors that limit pearl millet productivity are not yet studied (Disasa et al., 2016). All agronomic practices (seed rate, fertilizer rate, spacing and other agronomic practices) were done depending on the agronomic packages settled to sorghum production.

Wag-himra administrative zone is one of the known dry land areas in Ethiopia. Especially low land areas receives limited amount of rainfall (not more than $275 \mathrm{~mm}$ annually) and the growing period is very short usually. The rainfall amount and distribution are highly variable and erratic in nature. The soils are highly degraded and low in fertility. Pearl Millet is grown in harsh environments where other crops grow or yield poorly (Disasa et al., 2016; Negi et al., 2017).

Production of pearl millet with yield improvement would have a direct impact on the drought prone areas of Ethiopia since pearl millet is drought tolerant and early maturing with high water use efficiency. In order to improve pearl millet yield in the study area there is need to include the Intra and inter row spacing is crucial (Champion and Fuller, 2018). Especially in wag himira Zone, production of pearl millet needs critical attention since drought is the major problem in this area because moisture is the limiting factor for crop production in general and pearl millet production in particular (Jukanti et al., 2016). Sekota dryland agricultural research center has registered Kolla -1 pearl millet Varity through adaptation for production of low land areas of Wag himra zone, however, information on their intra and inter-rows spacing on yield and yield components are lacking (Ullah et al., 2017; Venkateswaran et al., 2019).

To address the further research works on production gaps in Wage-Himra administration zone using Kolla-1 pearl millet variety. Therefore, this research study was initiated with to increase the productivity of pearl millet in the study areas of Wag-Himra Zone through optimizing its intra and inter-row spacing.

\section{MATERIALS AND METHODS}

\section{Study area}

The experiment was conducted at Abergele and Aybra testing sites of Sekota dryland agricultural research center in Eastern Amhara region, Ethiopia during the main cropping season for one year (2014). Abergele testing site has been characterized by an altitude of 1495 m.a.s.l, minimum and maximum temperatures of $28^{\circ} \mathrm{C}$ and $42^{\circ} \mathrm{C}$ and an average annual rainfall of 250 to $650 \mathrm{~mm}$ with latitude of $12^{\circ} 62^{\prime} 83^{\prime \prime} \mathrm{N}$ and $39^{\circ} 03^{\prime} 56^{\prime \prime} \mathrm{E}^{\prime}$, whereas, Aybra testing site also characterized as an altitude of $1976 \mathrm{~m}$ minimum and maximum temperatures of $26.6^{\circ} \mathrm{C}$ and $31.6^{\circ} \mathrm{C}$ and an average annual rainfall of 500 to $650 \mathrm{~mm}$ with latitude of $12^{\circ} 68^{\prime} 35^{\prime \prime} \mathrm{N}$ and with longitude of $39.01^{\prime} 41^{\prime \prime} \mathrm{E}$.

\section{Experimental and treatment design}

The treatments considered in the study were consisting of four intra row spacing's $(5,10,15$ and $20 \mathrm{~cm}$ ) and four inter-row spacing $(30,50,60$ and $75 \mathrm{~cm})$ and making a total of sixteen treatments. The Randomized Complete Block Design factorial arrangement with three replications of plot size of $5 \mathrm{~m} \times 3 \mathrm{~m}$ was used. Blanket recommendations of Urea and DAP fertilizer $(50 \mathrm{~kg} / \mathrm{ha}$ and $100 \mathrm{~kg} / \mathrm{ha})$ were used as the source of $\mathrm{N}$ and $\mathrm{P}$, respectively. Application of urea was in two split, while the entire rate of phosphorus was applied at sowing in band. The experimental sites were prepared well. Each plot and block was separated by $0.50 \mathrm{~m}$ and $1.5 \mathrm{~m}$, respectively.

\section{Test crop variety and parameters}

Pearl millet variety Kolla-1 was used as a testing crop for the experiment. Important agronomic practices like land preparation and weeding were uniformly applied to all experimental plots as often as required. Days to heading, days to maturity, panicle length, Plant height at maturity $(\mathrm{cm})$, number of tillers and number of effective tillers per plant, lodging (\%), grain yield ( $\mathrm{kg} / \mathrm{ha})$, thousand seed weight ( $\mathrm{gm})$ and biomass yield ( $\mathrm{kg} / \mathrm{ha})$ were collected as growth and yield parameters of tef.

\section{Data collection and statistical analysis}

Data of many important growth and yield parameters collected during the experimental periods were purified and arranged for further analysis. The analysis of variance (ANOVA) was carried out for growth and yield parameters of the following statistical procedures appropriate for the experimental design using statistical analysis system (SAS) program package version 9.0 (SAS, 2002). Whenever treatment effects were significance at 0.01 or 0.05 level of significance errors, the means were separated by using the Duncan (Ducnan, 1995) multiple range test (DMRT) procedures at 0.05 probability level of significance.

\section{RESULTS AND DISCUSSION}

\section{Effect of row spacing on yield}

The analysis of variance revealed that Grain yield was significantly $(P<0.05)$ affected by in case of inter row spacing's, whereas there was no significance difference $(P>0.05)$ in case of intra row spacing. The interaction between inter row and intra row spacing was also not statistically significance $(P>0.05)$ at Abergele in the year 2014 cropping seasons (Table 1). The highest grain yield (1056 kg/ha) was recorded from $50 \mathrm{~cm}$ inter row spacing The lowest grain yield (793 and $837 \mathrm{~kg} / \mathrm{ha}$ ) was recorded from $60 \mathrm{~cm}$ and $75 \mathrm{~cm}$ inter row spacing respectively at Abergele location in year 2014 cropping seasons. The current result not in line with (Yoseph, 2014) who found that yield and yield component of pearl millet cannot affect by different inter row spacing. But slightly similar with (Gulia et at., 2007) who reported that for consistent high grain yield of pearl millet row spacing of $36-53 \mathrm{~cm}$ is better than other. 
Interactive effects of row spacing on crop parameters

The result indicated that there was no significance difference $(P>0.05)$ on the parameters of days to maturity, number of tillers, number of effective tillers, plant height, panicle length, lodging percentage and biomass yield by the main effects of intra and inter row spacing as well as their interaction for the year 2014 cropping season. The current finding agreed with the result of (Anshul et al., 2017). Who found that no significance difference was observed on the parameters of days to maturity, number of tillers, number of effective tillers, plant height, panicle length, thousand seed weight and biomass yield by the main effects of intra.

The result indicated that there was no significance difference $(P>0.05)$ all the parameters like days to maturity, number of tillers, number of effective tillers panicle length, plant height lodging percentage, biomass yield, thousand seed weight and grain yield by the main effects of seeding rate and inter row spacing as well as The interaction between inter row and intra row spacing was also not statistically significance $(P>0.05)$ at Aybra in the year 2014 cropping seasons.

Table 1. Mean grain yield and other agronomic parameters of pearl millet on the effects of inter row spacing and intra row spacing at Abergele in 2014 cropping seasons.

\begin{tabular}{lcccccccccc}
\hline Inter row spacing & DAH & DAM & NT & NET & LP & PH & LDG & BM (kg) & TSW (gr) & G.Y (k.g) \\
\hline 30 & 60.54 & 81.66 & 1.93 & 1.18 & 18.32 & 156.36 & 51.36 & 2884.8 & 6.50 & $974^{\text {ab }}$ \\
50 & 57.69 & 82.23 & 1.78 & 1.13 & 18.26 & 150.24 & 46.55 & 3020.5 & 6.50 & $1056^{\mathrm{a}}$ \\
60 & 57.69 & 81.66 & 1.91 & 1.17 & 18.11 & 152.95 & 43.33 & 2658.3 & 6.54 & $793^{\mathrm{b}}$ \\
75 & 57.69 & 83.22 & 1.85 & 1.20 & 18.55 & 153.42 & 41.66 & 3207 & 6.41 & $837^{\mathrm{b}}$ \\
Means & 58 & 82 & 1.86 & 1.16 & 18 & 152 & 45 & 2920 & 6.40 & 90 \\
CV & 5.8 & 2.98 & 13.95 & 13.95 & 20.57 & 9.58 & 22.7 & 25.93 & 3.70 & 29.2 \\
Duncan at 5\% & $\mathrm{ns}$ & $\mathrm{ns}$ & $\mathrm{ns}$ & $\mathrm{ns}$ & $\mathrm{ns}$ & $\mathrm{ns}$ & $\mathrm{ns}$ & $\mathrm{ns}$ & $\mathrm{ns}$ & $*$ \\
Intra row spacing & & & & & & & & & \\
5 & 57.58 & 81.25 & 1.86 & 1.86 & 18.35 & 149 & 48.33 & 2827 & 6.54 & 1037 \\
10 & 58.66 & 83.58 & 1.79 & 1.12 & 18.36 & 154.61 & 48.33 & 2988 & 6.50 \\
15 & 58.50 & 81.25 & 1.84 & 1.21 & 18.25 & 154.13 & 44.16 & 3011 & 6.43 & 940 \\
20 & 58.11 & 81.33 & 1.94 & 1.17 & 18.20 & 155.15 & 41.66 & 2870 & 6.50 & 769 \\
Duncan at 5\% & $\mathrm{ns}$ & $\mathrm{ns}$ & $\mathrm{ns}$ & $\mathrm{ns}$ & $\mathrm{ns}$ & $\mathrm{ns}$ & $\mathrm{ns}$ & $\mathrm{ns}$ & $\mathrm{ns}$ & $\mathrm{ns}$ \\
\hline
\end{tabular}

Where, $\mathrm{DH}=$ Days to heading, $\mathrm{DM}=$ Days to maturity, $\mathrm{PH}=$ Plant height, NT=Number of tillers per plant, NET, Number of effective tiller HL=Head length BMY= Bio-mass, and GY=Grain yield. And NS, Non significance, ${ }^{*}$ Statistically significant and ${ }^{* *}$ Statistically highly significance.

Table 2. Mean grain yield and other agronomic parameters of pearl millet on the effects of inter row spacing and intra row spacing at Aybra in 2014 cropping seasons.

\begin{tabular}{|c|c|c|c|c|c|c|c|c|c|c|}
\hline Inter row spacing & DAH & DAM & NT & NET & LP & $\mathrm{PH}$ & LDG & BM (k.g) & TSW (gr) & G.Y (k.g) \\
\hline 30 & 46.54 & 81.25 & 2.31 & 1.93 & 16.90 & 146.54 & 4.74 & 1721 & 8.40 & 739.38 \\
\hline 50 & 46.38 & 83.58 & 2.19 & 1.74 & 17.80 & 149.40 & 4.82 & 1642 & 8.50 & 734.22 \\
\hline 60 & 46.66 & 81.75 & 2.16 & 1.71 & 18.16 & 152.90 & 4.64 & 1816 & 7.78 & 664.89 \\
\hline 75 & 46.88 & 81.33 & 2.26 & 1.76 & 17.22 & 144.72 & 4.81 & 1648 & 7.33 & 710.64 \\
\hline Means & 46.00 & 91.00 & 2.2 & 1.78 & 17.61 & 148 & 4.76 & 1689 & 8.00 & 701.98 \\
\hline CV & 2.94 & 4.98 & 6.19 & 15.45 & 19.4 & 7.21 & 16.8 & 20 & 16.80 & 17.83 \\
\hline Duncan at $5 \%$ & ns & ns & ns & ns & ns & ns & ns & ns & ns & ns \\
\hline \multicolumn{11}{|l|}{ Intra row spacing } \\
\hline 5 & 45.75 & 89.16 & 2.21 & 1.16 & 17.31 & 149.5 & 2827 & 4.82 & 8.37 & 1775.59 \\
\hline 10 & 47.00 & 92.50 & 2.16 & 1.12 & 17.88 & 150.11 & 2988.9 & 4.92 & 7.62 & 1624.3 \\
\hline 15 & 47.16 & 91.25 & 2.35 & 1.21 & 17.71 & 148.48 & 2971.1 & 4.48 & 7.93 & 1628.6 \\
\hline 20 & 46.44 & 91.22 & 2.60 & 1.17 & 17.26 & 146.15 & 2870.4 & 4.80 & 8.16 & 1854.4 \\
\hline Duncan at $5 \%$ & ns & ns & ns & ns & ns & ns & ns & ns & ns & ns \\
\hline
\end{tabular}

Where, $\mathrm{DH}=$ Days to heading, $\mathrm{DM}=$ Days to maturity, $\mathrm{PH}=$ Plant height, $\mathrm{NT}=$ Number of tillers per plant, NET, Number of effective tiller HL=Head length BMY $=$ Bio-mass, and GY=Grain yield. And NS, Non significance, ${ }^{*}$ Statistically significant and ${ }^{* *}$ Statistically highly significance. 
The Combined analysis of inter row spacing by location showed significance difference $(P<0.05)$ for the parameters of grain yield and days to heading for the year 2014. The heights grain yield was recorded from $50 \mathrm{~cm}$ inter row spacing (895 kg/ha) whereas the lowest grain yield was recorded from $60 \mathrm{~cm}$ $(772 \mathrm{~kg} / \mathrm{ha})$ and $75 \mathrm{~cm}(777 \mathrm{~kg} / \mathrm{ha})$. There was no significance difference between the treatments of $30 \mathrm{~cm}$ and $50 \mathrm{~cm}$ inter row spacing on the grain yield. The heights days to heading was recorded from $30 \mathrm{~cm}$ inter row spacing, whereas the lowest days to heading was recorded from $60 \mathrm{~cm}$ and $50 \mathrm{~cm}$ inter row spacing's respectively and there was no significance differences between the treatments of $50 \mathrm{~cm}, 60 \mathrm{~cm}$ and $75 \mathrm{~cm}$ inter row spacing's for the parameter of days to heading. Based on the combined analysis by location the main effect of inter row spacing had no significance effect on the parameters of days to maturity, number of tillers, number of effective tillers, panicle length, thousand seed weight and biomass yield for the year
2014 cropping season. The Combined analysis of intra row spacing by location showed significance difference $(P<0.05)$ for the parameter of grain yield for the year 2014 . The heights grain yield was recorded from $5 \mathrm{~cm}$ intra row spacing $(906 \mathrm{~kg} / \mathrm{ha}$ ) whereas the lowest grain yield was recorded from $20 \mathrm{~cm} 687 \mathrm{~kg} / \mathrm{ha}$ ). There was no significance difference between the treatments of $5 \mathrm{~cm}$ and 10 $\mathrm{cm}$ intra row spacing. Intra row spacing had no significance effect on days to heading, days to maturity, number of tillers, number of effective tillers, panicle length, thousand seed weight and biomass yield for the year 2014 cropping season. The current result goes in line with (Anshul et al., 2017; Ullah et al., 2017) who found that different intra row spacing did not show significance difference on the parameters of number of tillers, number of effective tillers, plant height, thousand seed weight and panicle length on pearl millet whereas different intra row spacing had significant effect on the grain yield of pearl millet (Champion and Fuller, 2018; Chisi and Peterson, 2019).

Table 3. Mean grain yield and other agronomic parameters of pearl millet as affected by intra and inter row spacing combined by location for the year 2014 at Aybra and Abergele locations.

\begin{tabular}{|c|c|c|c|c|c|c|c|c|c|c|}
\hline Inter row spacing & DAH & DAM & NT & NET & LP & $\mathrm{PH}$ & LDG & BM (k.g) & TSW (gr) & G.Y (k.g) \\
\hline 30 & $53.5^{a}$ & 85.95 & 2.12 & 1.52 & 17.61 & 151.45 & 28 & 1812 & 7.45 & $856 a$ \\
\hline 50 & $52^{b}$ & 87.23 & 1.98 & 1.44 & 18.03 & 149.82 & 25.68 & 1877 & 7.50 & $895 a$ \\
\hline 60 & $51.75^{b}$ & 86 & 2.04 & 1.44 & 18.14 & 152.92 & 23.98 & 1661.6 & 7.16 & $772 b$ \\
\hline 75 & $52.29^{\mathrm{ab}}$ & 87 & 2.01 & 1.48 & 18.05 & 147.65 & 22 & 1889 & 6.87 & $777 b$ \\
\hline Means & 52.37 & 86.63 & 2.04 & 1.47 & 17.96 & 150.42 & 24.82 & 1811 & 7.24 & 800 \\
\hline$C V$ & 4.45 & 4.16 & 13.29 & 19 & 6 & 8.59 & 9.73 & 27 & 15 & 25 \\
\hline Duncan at $5 \%$ & $*$ & ns & ns & ns & ns & ns & ns & ns & ns & $*$ \\
\hline \multicolumn{11}{|l|}{ Intra row spacing } \\
\hline 5 & 52.66 & 85 & 2.04 & 1.48 & 17.83 & 149.22 & 26.57 & 1801 & 7.45 & $906^{a}$ \\
\hline 10 & 52.83 & 88 & 1.97 & 1.37 & 18.12 & 152.36 & 26.62 & 1845 & 7.33 & $821^{a b}$ \\
\hline 15 & 52.63 & 86.86 & 2.07 & 1.51 & 18.09 & 149.7 & 23.12 & 1831 & 7.18 & $771^{\mathrm{bc}}$ \\
\hline 20 & 52.27 & 86.27 & 2.05 & 1.52 & 17.73 & 150.65 & 23.23 & 1745 & 7.33 & $687^{c}$ \\
\hline Duncan at 5\% & NS & ns & ns & ns & ns & ns & ns & ns & ns & * \\
\hline
\end{tabular}

Where, $\mathrm{DH}=$ Days to heading, DM=Days to maturity, $\mathrm{PH}=$ Plant height, $\mathrm{NT}=$ Number of tillers per plant, NET, Number of effective tiller HL=Head length BMY= Bio-mass, and GY=Grain yield. And NS, Non significance, ${ }^{*}$ Statistically significant and ${ }^{* *}$ Statistically highly significance.

\section{Conclusions}

In general, main effect of different inter row spacing had significance effect on the grain yield of pearl millet at Abergele location, whereas the main effect and the interaction between intra and inter row spacing had no significance effect all other parameters at Abergele location for the year 2014 cropping season. The main effects of inter and intra row spacing and their interaction had no significance effect all the parameters at Aybra location in the year 2014 cropping season, but the combined analysis by location showed significance difference on the main effects of inter row spacing and intra row spacing for the parameters of grain yield, similarly the main effects of inter row spacing had significance effect on the parameters of days to heading, whereas the interaction between inter row spacing and intra row spacing had no significance effect for all the parameters. Thus, it is possible to recommend that, sowing of pearl millet with inter row spacing of $50 \mathrm{cmand} 5 \mathrm{~cm}$ intra row spacing is effective in attaining higher grain yield in the study area.

\section{ACKNOWLEDGEMENTS}

We would like to say thank Sekota Dryland Agricultural Research Centre (SDARC) and Amhara Agricultural Research Institute (ARARI) for the financial support to conduct the experiment properly.

Open Access: This is an open access article distributed under the terms of the Creative Commons Attribution 4.0 License, which permits unrestricted use, distribution, and reproduction in any medium, provided the original author(s) if the sources are credited. 


\section{REFERENCES}

Anshul, G., Sharma, O.P., Solanki, R.B. and Verma, H.P. (2017). Growth and yield of pearlmillet [Pennisetum glaucum (L). R. Br.] as influenced by varieties and bio-regulators. Environment and Ecology, 35(2): 785-788, https://www.cabdirect.org/cabdirect/abstract/20173151645

Champion, L. and Fuller, D.Q. (2018). New evidence on the development of millet and rice economies in the Niger river basin: archaeobotanical results from Benin. In Plants and People in the African Past. Springer, Cham, pp. 529-547.

Chisi, M. and Peterson, G. (2019). Breeding and Agronomy. In Sorghum and Millets. AACC International Press. pp. 23-50, https://doi.org/10.1016/B978-0-12-811527-5.00002-2

Disasa, T., Feyissa, T., Admassu, B., Paliwal, R., De Villiers, S.M. and Odeny, D.A. (2016). Molecular evaluation of Ethiopian sweet sorghum germplasm and their contribution to regional breeding programs. Australian Journal of Crop Science, 10(4): 520.

Duncan, D.B. (1955).Multiple Range and Multiple F. Test. Biometrics, 11: 1- 42.

FAO (2000). Food and Agriculture Organization of the United Nations: Bulletin o Statistics. Rome, 1: 16-36.

Gulia, S.K., Wilson, J.P., J. Carter, and Singh, B.P. (2007). Progress In Grain Pearl Millet Research And Market Development. In: J. Janick and A. Whipkey (Eds.). ASHS Press, Alexandria, VA, pp. 32.

Jukanti, A.K., Gowda, C.L., Rai, K.N., Manga, V.K. and Bhatt, R.K. (2016). Crops that feed the world 11. Pearl Millet (Pennisetum glaucum L.): an important source of food security, nutrition and health in the arid and semi-arid tropics. Food Security, 8(2): 307-329, https://doi.org/10.1007/s12571-016-0557-y

Kodkany, B.S., Bellad, R.M., Mahantshetti, N.S., Westcott, J.E., Krebs, N.F., Kemp, J.F. and Hambidge, K.M. (2013).
Biofortification of pearl millet with iron and zinc in a randomized controlled trial increases absorption of these minerals above physiologic requirements in young children. The Journal of Nutrition, 143(9): 1489-1493, https://doi.org/10.3945/jn.113.176677

Mortimore, M., Anderson, S., Cotula, L., Davies, J., Faccer, K., Hesse, C. and Wolfangel, C. (2009). Dryland Opportunies: A new paradigm for people, ecosystems and development. International Union for Conservation of Nature (IUCN). Report. pp. 98.

Negi, S., Kumar, V. and Bhatt, A. (2017). Genetic diversity among Finger Millet [Eleusine coracana (L.) Gaertn] genotypes for yield and its contributing traits. International Journal of Current Microbiology and Applied Sciences, 6(8): 3332-3337.

Singh, P., Boote, K.J., Kadiyala, M.D.M., Nedumaran, S., Gupta, S.K., Srinivas, K. and Bantilan, M.C.S. (2017). An assessment of yield gains under climate change due to genetic modification of pearl millet. Science of the Total Environment, 601: 1226-1237, https://doi.org/10.1016/j.scitotenv.2017.06.002

Ullah, A., Ahmad, A., Khaliq, T. and Akhtar, J. (2017). Recognizing production options for pearl millet in Pakistan under changing climate scenarios. Journal of integrative agriculture, 16(4): 762-773, https://doi.org/10.1016/S2095-3119(16)61450-8

Venkateswaran, K., Elangovan, M. and Sivaraj, N. (2019). Origin, Domestication and Diffusion of Sorghum bicolor. In Breeding Sorghum for Diverse End Uses. Woodhead Publishing, pp. 15-31.

Vinoth, A. and Ravindhran, R. (2017). Biofortification in millets: a sustainable approach for nutritional security. Frontiers in Plant Science, 8: 25-29, https://doi.org/10.3389/fpls.2017.00029

Yoseph, T. (2014). Evaluation of Moisture Conservation Practices, Inter and Intra Row Spacing on Yield and Yield Components of Pearl Millet (Pennisetum glaucum) at Alduba, Southern Ethiopia. Evaluation, 4(9): 1-10. 